Dragan Obradović, $\mathbf{P h D}^{*}$

\title{
THE SUBJECT MATTER OF ENDANGERING ROAD TRAFFIC IN THE CRIMINAL LEGISLATION SYSTEMS OF THE FORMER YUGOSLAV REPUBLICS
}

\author{
Abstract
}

This paper gives an analogous analysis of the legislations of the former Yugoslavia republics (Serbia, Croatia, Slovenia, Montenegro, Bosnia-Herzegovina and Macedonia) regarding criminal offenses against road traffic safety. The similarities and differences with the law of the Republic of Serbia, which is the result of a common legal tradition, were highlighted. The similarities and differences were examined with the case of the criminal offense of endangering road traffic taken into consideration, one which is prescribed in all analyzed legislation systems and the one most commonly reported in practice. Legislative solutions related to the prescribed sanctions (penalties and security measures) were also compared. Based on a comparative analysis, the author proposes amendments to the existing legislation of the Republic of Serbia by foreseeing serious bodily injury of the participants in traffic as an objective condition of the penalty.

Keywords: criminal offense, endangering road traffic, foreign legislation, penalties, security measures.

\section{Introduction}

The number of traffic accidents worldwide increases every year. Earlier mortality data shows that "one million more of deaths from injuries occurred in 2010 (5.1 million) than two decades earlier, with a total increase of $24 \% "$. At the same time, 20 to 50 million people were

\footnotetext{
* Judge, High Court of Valjevo, Serbia, Assistant Professor at the Faculty of Health, Legal and Business Studies in Valjevo, Singidunum University, Belgrade, Scientific Associate, e-mail: dr.gaga.obrad@gmail.com. ${ }^{1}$ R. Lozano et al., ,Global and regional mortality from 235 causes of death for 20 age groups in 1990 and 2010: a systematic analysis for the Global Burden of Disease Study 2010“, Lancet, Vol. 380, 2012, 2113.
} 
injured, while the economic costs of the consequences of such traffic accidents can be counted in billions of dollars. ${ }^{2}$ According to 2011 World Health Organization (WHO) indicators, are predicting that by 2030, traffic accidents with fatalities will become the $5^{\text {th }}$ leading cause of death, with a markedly pronounced difference in high and low income countries, unless certain measures and actions are taken to provide prevention in road traffic. The WHO proclaimed decade of 2011-2020 as an Action for Road Safety. According to the current WHO data about road safety, every year in road traffic accidents (predominantly in low- and middle-income countries), approximately 1.35 million people die, whereas between 20 and 50 million more suffer non-fatal injuries ${ }^{3}$.

In Europe it is generally a low death rate in traffic accidents, but WHO data from 2018 show that death rate in road traffic accidents is significant in countries, especially from former Socialist Federative Republic of Yugoslavia (Serbia, Croatia, Bosnia and Herzegovina, Montenegro, Macedonia and Slovenia) and varies from 6.3 (Slovenia, Macedonia) up to 15.7 (Bosnia and Hercegovina $)^{4}$. All six former Yugoslav republics that became independent states after the breakdown of the former Socialist Federal Republic of Yugoslavia (hereinafter: Yugoslavia) are centered in an area of some of the most important European routes: Corridor 10 - passing through Slovenia, Croatia, Serbia and Macedonia, a road and rail between Salzburg (Austria) and Thessaloniki (Greece); Corridor 5 - passing through Slovenia, the route from Venice (Italy) to Lvov (Ukraine), while some of the branches of that road or railway networks pass through Croatia and Bosnia, as well; Corridor 7 - the Danube waterway that passes through Croatia and Serbia on the route from Schwarzwald (Germany) to Constanta (Romania); and Corridor 8 , which is a road and rail network from Bari (Italy) on its way to Varna (Bulgaria) passing through Macedonia. ${ }^{5}$ The amount of traffic on these roads undoubtedly affects the frequent occurrence of road traffic accidents involving both locals and foreigners. Therefore, the question arises - whether the laws of the mentioned countries regulate criminal offenses against road traffic safety and whether there are differences that would affect unequal criminality of potential offenders. The base of the comparative analysis is

\footnotetext{
${ }^{2}$ G. Jacobs, A. Aeron-Thomas, A. Astrop, Estimating global road fatalities, Crowthorne (TRL Report 445), 2012, 9-11, http://citeseerx.ist.psu.edu/viewdoc/download?doi=10.1.1.174.5207\&rep $=$ repl\&type $=p d f$.

${ }^{3}$ WHO, Road Traffic Injuries, 2018, https://www.who.int/news-room/fact-sheets/detail/road-traffic-injuries.

${ }^{4}$ WHO, Road Traffic Injuries, Table A2, Road Traffic Deaths (Country List), 2018, https://www.who.int/ violence_injury_prevention/road_safety_status/2018/Table_A2_Road_Traffic_Deaths.pdf?ua $=1$.

${ }_{5}^{5}$ Pan-European corridors, http://www.pks.rs/e-learning/fiata/osnove/geografija/koridor.htm, last accessed on December 10, 2018.
} 
the criminal offense of endangering road traffic, which is prescribed in all the above mentioned legislations and the one that oftenest occurs in practice.

\section{Historical review}

Traffic-related offenses were first written in the Criminal Code of the Kingdom of Yugoslavia ${ }^{6}$ on January 27, 1929, and were applied to the entire area of the common state to which Serbia belonged to from January 1, 1930. Criminal acts against traffic were classified together with criminal offenses against the safety of people and property in a single Chapter 18 entitled: Criminal offenses against the road traffic safety for people, property and newspapers (par. 204 to 213). These were related to two separate offenses: endangering traffic safety on the streets, roads or squares (par. 204) and endangering the safety of other types of traffic (par. 206): railway, tram, air and maritime traffic. Both criminal offenses had qualifying forms envisaged in par. 205 and 207. The qualified circumstances were related to the severity of the consequences (endangering a large number of persons or the occurrence of significant consequences - serious body harm or death). The Code foresaw that the crimes committed in traffic out of intent and that of negligence could be held as accountable.

All subsequent criminal laws that were applied on the territory of Yugoslavia in the period after the World War II, first of all federal and then the republic and provincial, regulated similarly the area of traffic crimes. It is interesting to note that in older laws, criminal offenses against road traffic safety were foreseen in the same section as criminal charges against the general safety of people and property and only later were the criminal offenses against road traffic safety separated into a different group.

The first codification mentioning criminal offenses against road traffic safety is the FNRY Criminal Code from 1951 (hereinafter: CC 51), ${ }^{7}$ which was applied on the territory of Yugoslavia from July 1, 1951 to 1977, with amendments to the legal text. Criminal offenses against the safety of public transport were prescribed in Chapter XXI in the chapter criminal offenses against the general safety of people and property (Art. 268-278). Furthermore,

\footnotetext{
${ }^{6}$ Krivični Zakonik Kraljevine Jugoslavije [The Criminal Code of the Kingdom of Yugoslavia], Službene novine Kraljevine Jugoslavije[Official Gazette of the Kingdom of Yugoslavia], no. 33 dated Feb. 9, 1929 with amendments in no. 295 dated Dec. 24, 1930 and no. 245 dated Oct. 20, 1931. The Code provision commentary in: M. Čubinski, Naučni i praktični komentar Krivičnog zakonika Kraljevine Jugoslavije, [ Scientific and practical commentary of the Criminal Code of the Kingdom of Yugoslavia], Geca Kon, Beograd 1934, 370-374.

${ }^{7}$ Krivični zakon FNRJ [Criminal Code of FRY], Off. Gazette of the FNRY, no. 13/51, 31/59, 11/62, 37/62, Krivični zakon SFRJ [Criminal Code of SFRY], Off. Gazette of the SFRY, 15/65, 15/67, 20/69 and 11/73.
} 
that group contained four criminal acts pertaining to road traffic safety. From that number, three crimes were related exclusively to road traffic safety and were passed into later criminal codes under the same name. These are the following: endangering public traffic (Art. 271), lack of proper supervision over road traffic (Art. 272), and dangerous transportation of explosives or inflammable materials (Article 274). The fourth crime is related to traffic safety, but it had a dependent character, since at the same time it included some of the most difficult forms of criminal offenses from this group and from the group against general security; namely, these are crimes against general security (Art. 271). Later laws also adopted the practice of a legal-technical separation of crimes against road traffic into a special chapter. For criminal offenses against road traffic safety, the perpetrator could have a penalty imposed with the driving license being revoked, as envisaged in Art. 61c.

According to Art. 271, par. 1 of the CC 51, only a driver of a motor vehicle could carry out the crime of endangering road traffic, or as the disposition of the said article read: "Whoever endangers road traffic on bridges and streets with dangerous or erratic driving thereby endangers people's lives or property on a large scale." Despite the fact that the disposition suggests that this is a delictum communium, the prescribed enforcement suggests that only certain categories of road users can commit this crime, such as drivers of motor vehicles, rigs and cyclists. ${ }^{8}$

Since 1977, there had been a duality in the regulations of criminal legislation. At the same time, federal and republic or provincial criminal laws were applied simultaneously. The SFRY Criminal Code, which was enacted in 1976 and entered into force on July 1, 1977 (hereinafter: SFRY CC), regulated general institutes of substantive criminal law and certain criminal offenses within the jurisdiction of federal institutions. For traffic crimes, it is significant that Art. 68 of the CC of the SFRY prescribed a ban on driving a motor vehicle, while crimes against air traffic safety were envisaged in a separate chapter, as SFRY was a signatory to international treaties dealing with these matters. In the later Federal Republic of Yugoslavia, the provisions of that federal law were contained in the so-called Basic Criminal Code ${ }^{9}$ (hereinafter: BCC). With the independence of the Republic of Serbia, all these matters, together with other content of the Criminal Code (hereinafter: $\mathrm{CC}$ ), have been consolidated in the Criminal Code passed in 2005.

\footnotetext{
${ }^{8}$ B. Nešković, "Krivična dela protiv bezbednosti javnog saobraćaja - Neka zapažanja i neka sporna pitanja", Sudska praksa, 3/1996, 58.

${ }_{9}^{9}$ Osnovni krivični zakon [The Basic Criminal Code], Sl. list SR Jugoslavije [Off. Gazette of the SRY] no. 35/92, 16/93, 31/93, 37/93, 24/94 and 61/01, Sl. glasnik R Srbije, [Off. Gazette of the RS], no. 39/03.
} 
The former republic's criminal codes passed in 1977 regulated crimes against road traffic safety on roads, railroads, ships or cable car traffic. In Serbia, they were regulated by the Criminal Code of the SR of Serbia, ${ }^{10}$ which was passed on June 30,1977, and came into force on July 1, 1977, to be later applied as the Criminal Code of the Republic of Serbia. Criminal offenses against road traffic safety were prescribed in the Criminal Code in Chapter 18 as a special group of criminal offenses. After the criminal offense of endangering road traffic due to a stupor (Art. 196) was deleted from the Criminal Code by changes in the criminal law from 1994 to date, the systematics, number and names of criminal offenses in the road traffic safety group were not substantially changed, except that the offenses against air traffic safety were added to the group of criminal offenses against road traffic safety in 2005.

\section{Road traffic violations in the legislation of Serbia, Croatia, Bosnia and Herzegovina, Montenegro, Macedonia and Slovenia}

All criminal legislations of the mentioned states from the territory of the former Yugoslavia contain special chapters that refer to a group of criminal offenses against road traffic safety. The comparative analysis is based on two criminal offenses: endangering road traffic and a crime against road traffic safety, as they are the most frequent offenses that occur in the practice of competent police authorities, public prosecutors and courts. The analysis of new legal solutions should show how the legal descriptions of criminal offence endangering road traffic are transformed. New legislatives, according to Dežman, have "inherited" many theoretical and practical dilemmas which were arising from the common legal tradition of the former Yugoslav state ${ }^{11}$.

\subsection{Serbia}

The Criminal Code of the Republic of Serbia (hereinafter: $\mathrm{CC})^{12}$ contains in a separate section in Chapter XXVI Criminal Offenses Against Road Traffic Safety, a total of 9 criminal offenses, five of which are related

\footnotetext{
${ }^{10}$ Krivični zakon R Srbije [Criminal law of the Republic of Serbia], Sl. glasnik SR Srbije [Off. Gazette of the SR Serbia], no. 26/77, 28/77, 43/77, 20/79, 24/84, 39/86, 51/87, 6/89, 42/89, 21/90, Sl. glasnik R Srbije [Off. Gazette of RSJ, no. 16/90, 49/92, 23/93, 67/93, 47/94, 17/95, 44/98,10/02, 11/02, 80/02, 39/03 and 67/03.

${ }^{11}$ Z. Dežman, „Kaznenopravna zaštita cestovnog prometa prema KZ Slovenije i KZ Hrvatske“, Hrvatski ljetopis za kazneno pravo i praksu, vol. 21, 1/2014, 137.

12 Krivični zakonik R Srbije [Criminal Code of the Republic of Serbia], Sl. glasnik RS [Off. Gazette of the Republic of Serbia] no. 85/05, 88/05, 107/05, 72/09,111/2009, 121/12, 104/13, 108/14 and 94/16.

Zakon o bezbednosti saobraćaja na putevima [Zakon o Law on Road Traffic Safety], Sl. glasnik RS [Off. Gazette of the Republic of Serbia], no. 41/09, 53/10,101/11,32/13, 55/14, 96/15, 9/16, 24/18.
} 
to road traffic. These are the following crimes: endangering road traffic (Art. 299 CC), endangering traffic by reckless driving and dangerous means (Art. 290 CC), lack of proper supervision over road traffic (Art. 295 CC), failure to provide assistance to persons injured in road accidents (Art. 296 CC) and the crime against road traffic safety (Art. 297 CC). Other crimes in this chapter are related to air or maritime traffic.

The practice of the basic form of the criminal offense of endangering road traffic referred to in Art. 299, par. 1 of the CC consists of a failure to comply with traffic regulations. This is defined as any action by traffic participants that is contrary to the regulations governing road trafficand which in turn endangers road traffic safety so that the lives of people or property on a large scale are at risk. The disposition is a blanket rule, so that the existence of a crime in a specific case depends on numerous regulations governing road traffic. The most important is the Law on Traffic Safety (hereinafter: LTS) ${ }^{13}$ with accompanying by-laws.

The individual, i.e. the perpetrator of a crime that endangers road traffic is an objectively important feature of the crime, as the crime can be perpetrated only by a traffic participant. A traffic participant is a person who takes part in traffic in any way (Art. 7, par. 67 LTS). In the case of crimes of endangering road traffic, the definition of the traffic participant is not only reserved for a driver, but also includes other categories of participants, as well as pedestrians.

The consequence of formulation of the basic form of crime is that the endangerment to road traffic is a concrete danger to the lives of people or property on a large scale. The criminal act of endangering public traffic can be done with intent and out of negligence.

In order for the behavior that corresponds to the description of the criminal offense referred to in Art. 279 to be punishable, it is necessary that the condition of punishment is fulfilled (objective condition of incrimination). Therefore, the condition is that the act of dangerous driving by traffic participants has caused property damage exceeding the amount of two hundred thousand dinars or a slight body injury.

Qualified forms of the criminal offense of endangering road traffic safety and all other criminal offenses from Chapter XXVI are prescribed in Art. 297 of the CC, titled: Severe acts against road traffic safety. The aforementioned criminal offense includes the most severe forms of the mentioned crimes with serious body injuries, death of a person or property damage on a large scale. According to the still valid legal understanding of the Criminal Department

${ }^{13}$ Zakon o bezbednosti saobraćaja na putevima [Law on Road Traffic Safety], Službeni glasnik RS [Off. Gazette of the RS], no. 41/09, 53/10,101/11,32/13, 55/14, 96/15, 9/16, 24/18, 
of the Supreme Court of Serbia (VSS), there is property damage on a large scale in certain forms of this criminal offense - from par. 1 and 3 when the damage exceeds the amount of $6,000,000$ dinars. ${ }^{14}$ In all forms of criminal offenses, the safety measure is the banning of the offender from driving a motor vehicle for the crime against road traffic safety.

\subsection{Macedonia}

The Criminal Code of the Republic of Macedonia (hereinafter: CCRM $)^{15}$ in a separate section in Chapter XXVII dealing with criminal offenses against road traffic safety contains a total of 8 criminal offenses, five of which refer to road traffic.

These are: endangering road traffic (Art. 297 CCRM), endangering traffic by reckless driving and transportation of dangerous goods (Art. 298 CCRM), lack of supervision over road traffic (Art. 299 CCM), failure to provideassistancetopersonsinjuredinaroadtrafficaccident(Art.301CCM) and crime against road traffic safety (Art. $300 \mathrm{CCM}$ ). The other criminal offenses from this chapter in the CCRM relate to air or maritime traffic. The provisions of the CCRM relating to the criminal offense of endangering road traffic (Art. 297 CCRM), or a severe crime against road traffic safety (Art. $300 \mathrm{CCM}$ ), are the same as those in the CC, except that the provisions relating to the criminal offense of endangering road traffic do not lay out a fine for damage as an objective condition of incrimination.

From CCRM in 2004 the prohibition of driving a motor vehicle has been categorized as punishment, and not as security measure as in the most of analyzed legislations ${ }^{16}$. Prohibition of driving a motor vehicle is an additional penalty. This punishment may be imposed if the offender has been sentenced to imprisonment or a fine has been imposed, or a suspended sentence or judicial remedy. The ban of driving a motor vehicle can be imposed on the offenders for a period from three months to five years, and can also be imposed as a single penalty for the perpetrator of negligence for which a fine or imprisonment of up to one year is prescribed if the offense has been committed under particularly mitigating circumstances.

\footnotetext{
${ }^{14}$ The legal opinion adopted at the session of the Criminal Department of the Supreme Court of Serbia on April 17, 2006, Court practice Bulletins of the Supreme Court of Serbia, 2006, no.1 and 2008, no. 4.

${ }^{15}$ Krivičen zakonik na R Makedonija [ Criminal law of Macedonia], Služben vesnik na Republika Makedonija, [ Off. Gazette of the Republic of Macedonia], no. 37/96, 80/99, 4/02, 43/03, 19/04, 81/05, 60/06, 73/06, 7/08, 139/08, 114/09, 51/11, 135/11, 185/11, 142/12, 166/12 and 55/13.

${ }^{16}$ Kambovski says that this way has reduced the scope of the legislative maneuver to sanctions that have a punitive character as security measures. V. Kambovski, Kazneno pravo, opšt del, Kultura, Skopje 2005, 820.
} 
When the offender is a professional driver, duration of the sentence may not be less than one year nor more than ten years. The court will be obliged to impose the said sentence if the offender committed the criminal offense of endangering road traffic under the influence of alcohol. When imposing a suspended sentence, the court may order that the conviction can be revoked if the offender violates the ban on driving a motor vehicle. Also, the ban can be set if the court has imposed a safety measure of compulsory psychiatric treatment and custody in a health institution, or at liberty for the offender.

\subsection{Montenegro}

The Criminal Code of Montenegro (hereinafter: $\mathrm{CCMN})^{17}$ in a separate section in Chapter XXVII entitled "Crimes against road traffic safety" contains a total of 10 criminal offenses, out of which 5 are related to road traffic. All these offenses correspond to the criminal offenses according to their respective crimes from the Criminal Code of the Republic of Serbia. These are: endangering road traffic (Art. $339 \mathrm{CCMN}$ ), endangering traffic by reckless driving and transportation of dangerous goods (Art. 340 $\mathrm{CCMN}$ ), lack of proper supervision over road traffic (Art. $346 \mathrm{CCMN}$ ), failure to provide assistance to injured persons in a road accident (Art. 347 $\mathrm{CCMN}$ ) and severe crimes against road traffic safety (Art. $388 \mathrm{CCMN}$ ). Other crimes in this chapter are related to air or maritime traffic.

The CCMN, within the framework of the provisions of the general part, provides the safety measure of a ban on driving a motor vehicle, which can be imposed on the offender optionally, for a period from three months up to five years. It is worth mentioning that the possibility of a permanent safety measure is foreseen in the following case: if the crime resulted in one or more traffic fatality, in the case that the offender has already been banned from driving. In addition, the ban on driving a motor vehicle may be imposed on offenders and punishable by imprisonment, fines, suspended sentence, judicial warning or the perpetrator can be free from punishment. If a perpetrator has been convicted with a suspended sentence, there is the possibility of revocation if the perpetrator violates the ban on driving a motor vehicle.

\footnotetext{
${ }^{17}$ Krivični zakonik Republike Crne Gore [Criminal Code of R of Montenegro], Sl. list RCG [Off. Gazette of the Republic Montenegro - MN], no. 70/03, 13/04, 47/06, Sl. list CG [Off. Gazette of MN], no. 40/08, 25/10, $32 / 11,64 / 11,40 / 13,56 / 13,14 / 15,42 / 15,58 / 15,44 / 17$ and 49/18.
} 
New solutions from the CCMN could be inspirational for the legislators of the Republic of Serbia. For example, in the legal formulation of a criminal offense, the endangerment to road traffic (Art. 339, par. 1) and all other criminal offenses in this group, there is a precise laying out of the objective requirement of incrimination, thus the need for interpretation of legal standards ceases. Thus, in Art. 339, par. 1, CCMN foresees that the act will be punishable if the damage to property exceeds the amount of 20,000 EUR, and in the case of a severe crime against the safety of road traffic referred to in Art. 348, par. 1 and 3, damage should exceed the amount of 40,000 EUR.

\subsection{Bosnia and Herzegovina}

The most complex legal system in relation to the others analyzed in this paper is one of the Republic of Bosnia andHerzegovina, in which there are four legal sub-systems: the legislation of Bosnia andHerzegovina, Republika Srpska, the Federation of Bosnia and Herzegovina and Brčko District. In each of these subsystems there is a special Criminal Code or Criminal Procedure Code.

Bosnia and Herzegovina, as a state consists of two entities and one district. It has Criminal Code (hereinafter: $\mathrm{CCBH}),{ }^{18}$ but separate provisions fail to lay out criminal offenses against road traffic. The only provision concerns the definition of the term 'means of transport' in Art. 1, par. 27. A means of transport shall be understood as "any vessel, vehicle and aircraft, as well as any other means which may be used for transport on land, water or air transport, regardless of type of operation."

\subsubsection{Federation of Bosnia-Herzegovina}

The Criminal Code of the Federation of Bosnia-Herzegovina $(\mathrm{CCFBH}){ }^{19}$ in a separate section in Chapter XXVIII "Criminal offenses against road traffic safety" contains a total of 6 criminal offenses that are all related to road traffic safety. These are crimes that, by their names but also legal descriptions correspond to individual crimes from the Criminal Code of the Republic of Serbia. This relates to the following crimes:

\footnotetext{
${ }^{18}$ Krivični zakon Bosne i Hercegovine [Criminal Code of Bosnia-Herzegovina], Službeni glasnik BiH [Off. Gazette of $B-H]$, no. 3/03, 32/03, 37/03, 54/04, 61/04, 30/05, 53/06, 56/06, 32/07, 8/10, 47/14, 22/15, 40/15 and 35/18.

${ }^{19}$ Krivični zakon Federacije BiH [Criminal Code of B-H Federation], Službene novine FBiH [Of. Gazette of FBH], no. 36/03, 37/03, 21/04, 69/04, 18/05, 42/10, 42/11, 59/14 and 76/14.
} 
endangering road traffic (Art. $322 \mathrm{CCFBH}$ ), endangering road traffic by reckless driving (Art. $334 \mathrm{CCFBH}$ ), lack of proper supervision over road traffic (Art. $355 \mathrm{CCFBH}$ ), severe crimes against road traffic safety (Art. $366 \mathrm{CC} \mathrm{FBH)} \mathrm{and} \mathrm{failure} \mathrm{to} \mathrm{provide} \mathrm{assistance} \mathrm{to} \mathrm{persons} \mathrm{injured} \mathrm{in}$ road traffic accidents (Art. $377 \mathrm{CCFBH}$ ). The only criminal offense that does not exist in the Criminal Code of the RS is the criminal offense of endangering public traffic due to stupor (Art. $333 \mathrm{CCFBH}$ ).

The framework of the criminal offense of endangering road traffic (Art. 332) regulates the improper traffic behavior of those who fail to comply with traffic regulations, thus endangering road traffic and the lives of people or property on a larger scale and therefore, property damage over 5,000 KM, regardless of whether the offense was committed with intent or out of negligence. The provision relating to severe crimes against road traffic safety (Art. 336) regulates the qualified forms of this criminal offense. They exist if, in the course of committing a danger to road traffic referred to in Art. 332 (as well as others from Chapter XXVIII of the $\mathrm{CCFBH}$ ), property damage on a large scale has been caused, or serious body injury of a person or one or more fatalities carried out with intent or out of negligence.

One of the security measures that can be imposed on the offender of these crimes is a ban on driving a motor vehicle, which in 2010 suffered a change of name and is now called the ban of managing a vehicle. It is carried out optionally for a period from three months to five years. The offender may be sentenced to imprisonment (in place of community service not fully implemented within a specified time limit) or a suspended sentence (with the possibility of revocation if the perpetrator violates the ban on driving a vehicle).

\subsubsection{Republic of Srpska}

The Criminal Code of the Republic of Srpska (hereinafter: the $\mathrm{CCRSr}^{20}$ contains criminal offenses against road traffic in Chapter XXXI. All five legal descriptions of criminal offenses are related to road traffic: endangering road traffic safety (Art, $402 \mathrm{CCRSr}$ ), endangering specific types of traffic (Art. $403 \mathrm{CCRSr}$ ), endangering road traffic by reckless driving or by using dangerous means (Art. 404 CCRSr), lack of proper supervision over road traffic (Art. $405 \mathrm{CCRSr}$ ), failing to assist

\footnotetext{
${ }^{20}$ Krivični zakonik R Srpske [Criminal Code of R Srpska], Službeni glasnik Republike Srpske [Off. Gazette of Republika Srpska], no. 64/2017.
} 
persons injured in road traffic accidents (Art. 406 CCRSr). The names of all criminal offenses and their legal descriptions are similar to the existing ones in the legal system of Republic of Serbia. The criminal offense of endangering road traffic (Art. 402) is perpetrated by a road user who fails to comply with traffic regulations and poses an imminent danger to people or property on a large scale. Punishment is imposed only when the unlawful act has caused serious body injury to another person. A criminal act can be carried out with intent or out of negligence.

The new 2017 Criminal Code of Republika Srpska brought enormous novelties in relation to the former Criminal Code of Republika Srpska (hereinafter: the old $\mathrm{CC}$ of $\mathrm{RSr})^{21}$ which was in force until the new CCRSr entered into force. First of all, the ban on driving a motor vehicle was changed from a security measure to a sentence. In fact, it can only be pronounced as a secondary sentence together with a prison sentence, a fine and a suspended sentence. The said secondary sentence can be imposed for a period of six months to five years (a longer period than previously). If the result was one or more fatalities, a secondary penalty for driving a motor vehicle may be imposed for a period of one to eight years. Similar to the solution in the Republic of Serbia's Criminal Code, the consequences of the violation of the ban on driving a motor vehicle are prescribed in the event that the accused drove a motor vehicle while the ban was enforced; the court is authorized to replace it with a ban of six months for every month of imprisonment.

In the legal description of the criminal offense of endangering road traffic (Art. 402, par. 1) there was a lack of the objective condition of incrimination in the form of the amount of property damage caused and serious body injury is prescribed as an objective incident of incrimination. A novelty is also the provision from par. 2 of Art. 402 which prescribes a severe crime in the case that the offender was under the influence of alcohol (over $1.50 \mathrm{~g} / \mathrm{kg}$ of alcohol in the blood) or narcotics during the criminal act of endangering road traffic safety, or driving $50 \mathrm{~km} / \mathrm{h}$ over the speed limit. This severe crime is penalized, along with a sentence of imprisonment, with a mandatory penalty. Mandatory punishment by a penalty is also prescribed for those severe crimes when reckless driving resulted in one or more fatalities, regardless of whether the offense was committed with intent or out of negligence.

\footnotetext{
${ }^{21}$ Krivični zakonik R Srpske [Criminal Code of R Srpska], Službeni glasnik Republike Srpske [Off. Gazette of Republika Srpska], no. 49/03, 108/04, 37/06, 70/06, 73/10, 1/12 and 67/13-Art. 410.
} 


\subsubsection{Brčko District}

The Criminal Code of Brčko District (hereinafter: CCBD) ${ }^{22}$ regulates criminal acts against road traffic safety in Chapter 28. Six offenses have been prescribed, which, according to their names and legal descriptions, correspond to certain crimes from the Criminal Code of the Republic of Serbia. Thus, the following criminal offenses are laid out: endangering road traffic (Art. 326), endangering road traffic by reckless driving (Art. 328), lack of proper supervision over road traffic (Art. 329), severe criminal offenses against road traffic safety (Art. 330) and failure to provide assistance to persons injured in road traffic accidents (Art. 331). Similarly to the CCBH, the Criminal Code of BD also lays out a criminal offense that does not exist in the Criminal Code, namely, the criminal offense of endangering road traffic due to stupor (Art. 327). The criminal offense of endangering road traffic (Art. 326) is regulated in the same way as in the legislation of the Republic of Serbia and involves the unlawful behavior of road traffic participants. The following is necessary for it to be qualified as a criminal offense: consequences of the criminal offense (endangering lives of people or property on a large scale) and fulfillment of the objective condition of punishment - the emergence of further consequences in the event of an injury (property damage exceeding $5,000 \mathrm{KM}$ or serious bodily harm). The offender is responsible regardless of whether they had acted with intent or out of negligence.

Legal-technical solutions similar to those in the former Yugoslav legislation were adopted by the CCBD: in particular, qualified forms of criminal offenses in the field of road traffic were regulated by the provision called severe crimes against road traffic safety (Art. 330), in a special way. The first severe form exists if it involves a criminal offense of endangering road traffic from Art. 326, par. 1 causing damage to property on a large scale, but the form referred to in par. 2 of the same article and other criminal offenses from the group against traffic safety requires the causing of serious body harm to a person. The severe forms exist if there is a qualifying circumstance in the form of one or more fatalities. Criminal offenses can be committed with intent or out of negligence.

The CCBD provides the safety measure of a ban on driving a motor vehicle. The measure is optional for the offender and may

\footnotetext{
${ }^{22}$ Krivični zakon Brčko Distrikta Bosne i Hercegovine [Criminal Code of Brčko District in Bosnia-Herzegovina], Službeni glasnik Brčko Distrikta Bosne i Hercegovine [Off. Gazette of Brčko District in B-H], no. $10 / 03,6 / 05,21 / 10$ and $9 / 13,33 / 13,26 / 16,33 / 17,50 / 18$.
} 
last from three months to five years (as in the Republic of Serbia). In addition, the underlined security measure may be imposed on offenders and punishable by a prison sentence (replacing a nonexecuted community service) or a suspended sentence, which may be revoked if the punishment violates the ban on driving a motor vehicle. It is shown that the three aforementioned laws in Bosnia-Herzegovina have adopted various formulations of the criminal offense of endangering road traffic safety, especially with regard to the objective conditions of punishment. Moreover, in the Brčko District and the Federation of BosniaHerzegovina, the criminal offense of endangering road traffic entails a traffic participant who, by unlawful conduct, has caused property damage exceeding the amount of KM 5,000 (Art. 326, p. 1 CCBD, CCBH and Art. $1 \mathrm{CCBH})$, while in the Republic of Srpska only the unlawful behavior in traffic which causes serious body harm to a person (Art. 410, p. 1 CCRSr) is punishable. The existence of differences leads to the citizens of BosniaHerzegovina having an unequal status.

\subsection{Croatia}

In 2011, a new Penal Code of the Republic of Croatia (hereinafter: CCRC) was adopted and entered into the force on January 1, 2013. ${ }^{23}$ Unlike the previous Criminal Code (the old CC of Croatia), ${ }^{24}$ in which systematics on the basis of the former Yugoslav legislation was abandoned, the criminal offenses against road traffic safety were classified in the general Chapter 20, which was entitled "Criminal offenses against general human security and property and traffic safety," a separate Chapter 22 was created in the new CC of the Republic of Croatia. This chapter classifies criminal offenses against road traffic safety. Out of the total of five criminal offenses, three legal descriptions refer to criminal offenses against road traffic safety, such as the following: endangering road traffic by reckless driving or dangerous means (Art. 224), irresponsible driving (Art. 226) and causing an accident in road traffic (Art. 277).

Causing an accident in road traffic (Art. 227), in addition to the changed name, essentially contains a legal description that corresponds to the previous criminal element of endangering road traffic (Art. 272 from

\footnotetext{
${ }^{23}$ Kazneni zakon R Hrvatske[Criminal Code of R Croatia], Narodne novine [Off. Gazette of Republic Croatia], no. 125/11, 144/12, 56/15, 61/15 i 101/17.

${ }^{24}$ Kazneni zakon R Hrvatske[Criminal Code of R Croatia], Narodne novine [Off. Gazette of Republic Croatia], no. 110/97, 27/98, 40/00, 129/00, 51/01, 111/03,190/03, 105/04, 84/05, 71/06, 110/07, 152/08 and 57/11.
} 
the old (CC). A criminal offense is defined as the behavior of a traffic participant who, by violating road traffic safety regulations, causes a traffic accident in which another person is seriously injured or there are one or more fatalities or property damage on a large scale. The crime is appropriate regardless of whether it was done with intent or out of negligence.

The offender can be penalized by the safety measure of a ban on driving a motor vehicle from one to five years in addition to a sentence or a suspended sentence. It is interesting that the CC of the Republic of Croatia lays out the optional possibility of pronouncing the mentioned security measure as a lifelong one, provided that, if the offender had previously committed a traffic violation, there is the expectation that even after the expiration of a five-year ban, the offender may recommit a criminal offense against road traffic safety. The possibility of reviewing the said decision on a lifetime ban of driving a motor vehicle upon the proposal of the offender has been introduced. However, if the proposal is adopted, the offender must retake the driving test. In the event that the court turns down the offender's proposal, the offender, after the expiration of a year, may repeat the proposal to review the decision on lifelong ban on driving a motor vehicle.

It is also curious that the Croatian code stipulated reckless driving as a separate criminal offense, even when only a specific danger to the lives of people was caused (a serious violation of traffic regulations under the influence of at least $1.5 \mathrm{~g} / \mathrm{kg}$ of alcohol, narcotics or psychoactive drugs or driving in the opposite direction, overtaking a line of vehicles in a noovertaking place, driving 50 kilometers per hour over the speed limit).

\subsection{Slovenia}

The Republic of Slovenia has retained the previous system inherent in the former Yugoslav legislation, by which criminal offenses against road traffic safety are laid out in a separate chapter. Chapter 31 of the Criminal Code of Slovenia (hereinafter: $\mathrm{CCS})^{25}$ mentions nine criminal offenses, five of which are related to criminal offenses against road traffic safety. These are causing a traffic accident by negligence (Art. 323), reckless driving in road traffic (Art. 324), endangering road traffic by reckless driving or by using dangerous means (Art. 326), lack of proper supervision over road traffic (Art. 327) and failure to provide assistance to persons injured in road

${ }^{25} \mathrm{C}$ Kazenski zakonik R Slovenije [Criminal Code of Slovenia], Uradni list R Slovenije [Off. Gazette of the $R S]$, no. 55/08, 66/08, 39/09 CC 1A, 91/11 CC 1B , 50/12 CC 1UPB 2, 6/16 CC 1UPB 2p, 54/15 KZ 1C, $38 / 16 \mathrm{CC} 1 \mathrm{D}$ and 27/17 CC 1E. 
traffic accidents (Art. 328). As in Croatian legislation, a criminal offense of reckless driving in road traffic was introduced in the Criminal Code, which was given a new name in the Criminal Code of Slovenia $1 \mathrm{~B}^{26}$ : dangerous driving in road traffic.

The CC of Slovenia lays out the ban on of driving a motor vehicle as one of three penalties, this being the secondary penalty that can be imposed with one of the two main sentences (imprisonment and fines), as well as a suspended sentence. The duration of the ban as a secondary penalty can not be shorter than six months or longer than two years, and a penalty may be imposed on the offender who commits the offense while using a motor vehicle. Of the six foreseen security measures that can be imposed, the penalties from this group of offenses include the safety measure of revoking the offender's driving license. Imposing the mentioned measure which can last from one to five years is conditional.

The offense of causing a traffic accident due to negligence (Art. $323 \mathrm{CCS}$ ) constitutes a violation of traffic regulations thereby which the offender causes a traffic accident in which another person suffers serious bodily harm. There is a serious crime if a qualified consequence is achieved (one or more fatalities). The offender can be punished by a fine or imprisonment for up to 3 years for the basic crime, while a sentence of up to eight years in prison and a ban on motor vehicle driving (cumulative) is predicted for serious forms. Paragraph 3 of the same Article lays out the conditions for the seizure of a motor vehicle.

It is important to note that the Road Traffic Regulations Act, ${ }^{27}$ in order to consistently separate traffic offenses from criminal offenses, classifies traffic accidents into four categories. Offenses are traffic accidents categories I and II, which result in property damage or minor injuries. Category III and IV traffic accidents are those involving serious bodily harm or fatalities. They qualify as a criminal offense under Art. 323 of the CC of Slovenia.

\section{4. (Non)compliance of the analyzed legislation}

Earlier systematics of criminal legislation and legal and technical formulations of legal descriptions of criminal offenses against road traffic safety influenced the manner in which the criminal offenses laid

\footnotetext{
${ }^{26}$ Off. Gazette of the $R S$, no. 91/11.

${ }^{27}$ Zakon o pravilima cestnega prometa [Law on road traffic], Uradni list RS [Off. Gazette of the Republic of Slovenia], no. 109/10.
} 
out in the new legislation of the states emerged on the territory of the former Yugoslavia. Therefore, there is a general similarity between the aforementioned legislation in that criminal offenses against road traffic safety are classified as a special group of criminal offenses (which is done in the $\mathrm{CC}$ of Croatia by subsequent amendments). In all the analyzed legislation, the greatest attention is focused on endangering road traffic. Such offenses belong solely in the CCFBH, CCRS and CCBD group against road traffic safety or in the group where they dominate by number (all other legislations). Further similarity is noted in the names and descriptions of the criminal offenses, in the definition of the term motor vehicle, in the accepted system of punishments, in which, in addition to the sentence or warning, a safety measure on the restrictions of driving a motor vehicle can be imposed on the offender.

The gradual changes in the legislation of the former Yugoslavia republics entail a distancing from the traditional solutions. The changes were incited by the need to ensure an effective protection of road traffic. Thus, in the general part of the CCM and the CCRSr, the ban on driving a motor vehicle is classified as a penalty, while in other legislations, the ban on driving a motor vehicle (CCMN, CCFBH, CCBDBH, CCC, and the Republic of Serbia) is considered a security measure. Slovenia is a special example, where the ban on driving a motor vehicle is defined as punishment, but the revoking of a driver's license is a security measure (exactly the opposite as in the Republic of Serbia's Criminal Code).

The traditional solution that it is enough to cause light bodily harm for an objective condition of incrimination to exist (sometimes alternatively, significant property damage in addition) is accepted by the Criminal Code of the Republic of Serbia, CCM, CCMN and CCFBH). In other legislations, however, even with the addition of reckless driving, the criminal offense of endangering road traffic safety narrows down the zone of incrimination. This is done by imposing serious bodily harm to another person by improper behavior in traffic as an objective condition of punishment (CCRSr, CCBDBH, CCC and CCS).

Regarding the amount of property damage as a further consequence of the criminal offense of endangering road traffic (objective condition of punishment), there are particular differences, since it is not foreseen as a condition of punishment at all (in Slovenia it is a violation), and other legislation systems, with the exception of Montenegro and the Republic of Croatia in whose legislation this is precisely defined, must specify the "property damage on a large scale" legal standard to the higher courts. 


\section{Conclusion}

After more than two decades since the break-up of the former Yugoslavia, the legislation systems of Serbia, Croatia, Bosnia andHerzegovina, Montenegro, Macedonia and Slovenia have noted great similarities in their criminal legislation systems. Criminal offenses against road traffic safety have been placed in a separate category, and within it, the predominant criminal offense is endangering road traffic safety. Similarities are the result of the accepted construction (for influence in German law) of the criminal offence of endangering as intentional criminal act, which can be committed also from negligence ${ }^{28}$. Comparisons of new legal solutions in Slovenia and Croatia are pointing out to problems in attempting to transform the basic dogmatic concept ${ }^{29}$. Therefore, in the law of Serbia, the current definition of the criminal offense of endangering traffic should be maintained.

Despite the fundamental similarities among the analyzed legislation systems, there are also some obvious differences, which are the result of the effort to improve general traffic safety in every each country. As a matter of fact, the observed differences could be inspirational to our lawmakers. They could improve legal solutions by foregoing the objective conditions of incrimination in the form of light body harm and property damage within the criminal offense of endangering road traffic safety. It would be sufficient to foresee serious body harm as an objective condition of incrimination. If the legislator, however, still retains the existing penalty conditions, it would be advisable to avoid legal standards in describing criminal offenses in the chapter of endangering road traffic safety. This can be done by accurately defining the amounts to be paid in the case of property damage.

\section{References}

Bavcon, Lj., „Varnost cestnega prometa in kaznovalno pravo“, in: Varnost cestnega prometa (ed. Dragan Petrovec), Inštitut za kriminologijo pri Pravni fakulteti, Ljubljana 2011, 11-25.

Čubinski, M., Naučni i praktični komentar Krivičnog zakonika Kraljevine Jugoslavije, Geca Kon, Beograd 1934.

Dežman, Z., „Kaznenopravna zaštita cestovnog prometa prema KZ Slovenije i KZ Hrvatske“, Hrvatski ljetopis za kazneno pravo i praksu, vol. 21,

\footnotetext{
${ }^{28}$ Lj. Bavcon, „,Varnost cestnega prometa in kaznovalno pravo“, in: Varnost cestnega prometa (ed. Dragan Petrovec), Inštitut za kriminologijo pri Pravni fakulteti, Ljubljana, 2011, 17-18, 21.

${ }^{29}$ Z. Dežman, 135, 139, 155.
} 
1/2014, 135-161.

Kambovski, V., Kazneno pravo, opšt del, Kultura, Skopje 2005.

Lozano, R, et al. „Global and regional mortality from 235 causes of death for 20 age groups in 1990 and 2010: a systematic analysis for the Global Burden of Disease Study 2010", Lancet, Vol. 380, 2012, 2095-2128.

Nešković, B., „Krivična dela protiv bezbednosti javnog saobraćaja - Neka zapažanja i neka sporna pitanja", Sudska praksa, 3/1996.

\section{Legal sources}

\section{Yugoslav legislation}

Krivični zakonik Kraljevine Jugoslavije [The Criminal Code of the Kingdom of Yugoslavia], Shuzbene novine Kraljevine Jugoslavije[Official Gazette of the Kingdom of Yugoslavia], dated Feb. 9, 2, 1929 with amendments in no. 295 dated Dec. 24, 1930 and no. 245 dated Oct. 20, 1931.

Krivični zakon FNRJ [Criminal Code of FRY], Off. Gazette of the FNRY, no. 13/51, 31/59, 11/62, 37/62. Krivični zakon SFRJ [Criminal Code of SFRY]Off. Gazette of the SFRY, 15/65, 15/67, 20/69 and 11/73.

Osnovni krivični zakon [The Basic Criminal Code], Sl. list SR Jugoslavije [Off. Gazette of the SRY] no. 35/92, 16/93, 31/93, 37/93, 24/94 and 61/01, Sl. glasnik R Srbije, [Off. Gazette of the RS] n, no. 39/03.

\section{Republic of Serbia}

Krivični zakon R Srbije [Criminal law of the Republic of Serbia], Sl. glasnik SR Srbije [Off. Gazette of the SR Serbia], no. 26/77, 28/77, 43/77, 20/79, 24/84, 39/86, 51/87, 6/89, 42/89, 21/90, Off. Gazette of RS, no. 16/90, 49/92, 23/93, 67/93, 47/94, 17/95, 44/98,10/02, 11/02, 80/02, 39/03 and 67/03.

Krivični zakonik R Srbije [Criminal Code of the Republic of Serbia], Sl. glasnik RS [Off. Gazette of the Republic of Serbia] no. 85/05, 88/05, 107/05, 72/09,111/2009, 121/12, 104/13, 108/14 and 94/16.

Zakon o bezbednosti saobraćaja na putevima [Zakon o Law on Road Traffic

Safety], Sl. glasnik RS [Off. Gazette of the Republic of Serbia], no. 41/09,

53/10,101/11,32/13, 55/14, 96/15, 9/16, 24/18.

Bilten sudske prakse Vrhovnog suda Srbije [Court practice Bulletin of the Supreme

Court of Serbia] 2006, br.1

Bilten sudske prakse Vrhovnog suda Srbije [Court practice Bulletin of the Supreme Court of Serbia], 4/2008. 


\section{Republic of Bosnia and Herzegovina}

Krivični zakon Bosne i Hercegovine [Criminal Code of Bosnia-Herzegovina], Službeni glasnik BiH [Off. Gazette of B-H], no. 3/03, 32/03, 37/03, 54/04, 61/04, 30/05, 53/06, 56/06, 32/07, 8/10, 47/14, 22/15, 40/15 and 35/18.

Krivični zakon Federacije BiH [Criminal Code of B-H Federation], Službene novine FBiH [Of. Gazette of FBH], no. 36/03, 37/03, 21/04, 69/04, 18/05, 42/10, 42/11, 59/14 and 76/14.

Krivični zakonik R Srpske [Criminal Code of R Srpska], Službeni glasnik Republike Srpske [Off. Gazette of Republika Srpska], no. 64/2017.

Krivični zakonik R Srpske [Criminal Code of R Srpska], Službeni glasnik Republike Srpske [Off. Gazette of Republika Srpska], no. 49/03, 108/04, 37/06, 70/06, 73/10, 1/12 and 67/13.

Krivični zakon Brčko Distrikta Bosne i Hercegovine [Criminal Code of Brčko District in Bosnia-Herzegovina], Službeni glasnik Brčko Distrikta Bosne i Hercegovine [Off. Gazette of Brčko District in B-H], no. 10/03, 6/05, $21 / 10$ and $9 / 13,33 / 13,26 / 16,33 / 17,50 / 18$.

\section{Republic of FYR Macedonia}

Krivičen zakonik na $\mathrm{R}$ Makedonija [Кривичниот законик на Република Македонија, Criminal law of Macedonia], Služben vesnik na Republika Makedonija, [Off. Gazette of the Republic of Macedonia], no. 37/96, 80/99, 4/02, 43/03, 19/04, 81/05, 60/06, 73/06, 7/08, 139/08, 114/09, $51 / 11,135 / 11,185 / 11,142 / 12,166 / 12$ and 55/13.

\section{Republic of Montenegro}

Krivični zakonik Republike Crne Gore [Criminal Code of R of Montenegro], Sl. list RCG [Off. Gazette of the Republic Montenegro - MN], no. 70/03, 13/04, 47/06, Sl. list CG [Off. Gazette of MN], no. 40/08, 25/10, 32/11, $64 / 11,40 / 13,56 / 13,14 / 15,42 / 15,58 / 15,44 / 17$ and $49 / 18$.

\section{Republic of Croatia}

Kazneni zakon R Hrvatske[Criminal Code of R Croatia], Narodne novine [Off. Gazette of Republic Croatia], no. 125/11, 144/12, 56/15, 61/15 i 101/17. Kazneni zakon R Hrvatske[Criminal Code of R Croatia], Narodne novine [Off. 
Gazette of Republic Croatia], no. 110/97, 27/98, 40/00, 129/00, 51/01, 111/03,190/03, 105/04, 84/05, 71/06, 110/07, 152/08 and 57/11.

\section{Republic of Slovenia}

Kazenski zakonik R Slovenije [Criminal Code of Slovenia], Uradni list $R$ Slovenije [Off. Gazette of the RS], no. 55/08, 66/08, 39/09 CC 1A, 91/11 CC 1B , 50/12 CC 1UPB 2, 6/16 CC 1UPB 2p, 54/15 KZ 1C, 38/16 CC 1D and 27/17 CC 1E.

Zakon o pravilima cestnega prometa [Law on road traffic], Uradni list RS [Off. Gazette of the Republic of Slovenia], no. 109/10.

\section{Website references}

Jacobs, G., Aeron-Thomas, A., Astrop, A., Estimating global road fatalities, Crowthorne (TRL Report 445), 2012, http://citeseerx.ist.psu.edu/viewdoc/ download?doi=10.1.1.174.5207\&rep=repl\&type $=p d f, 12.11 .2017$.

Pan-European corridors, http://www.pks.rs/e-learning/fiata/osnove/geografija/koridor.htm, last accessed on December 10, 2018.

WHO, Road Traffic Injuries, 2018, https://www.who.int/news-room/fact-sheets/detail/road-traffic-injuries, last accessed on December 10, 2018.

WHO, Road Traffic Injuries, 2018, Table A2, Road Traffic Deaths (Country List), https://www.who.int/violence_injury_prevention/road_safety_status/2018/ Table_A2_Road_Traffic_Deaths.pdf?ua=1, last accessed on December 10, 2018. 


\title{
Dr Dragan Obradović
}

Sudija Višeg suda u Valjevu

Docent na Fakultetu zdravstvenih, pravih i poslovnih studija u Valjevu

\section{UGROŽAVANJE DRUMSKOG SAOBRAĆAJA U KRIVIČNOM ZAKONODAVSTVU BIVŠIH JUGOSLOVENSKIH REPUBLIKA}

\author{
Rezime
}

Ovaj rad pruža analognu analizu zakonodavstava bivših jugoslovenskih republika (Srbije, Hrvatske, Slovenije, Crne Gore, Bosne i Herzegovine i Makedonije) u pogledu krivičnih dela protiv bezbednosti drumskog saobraćaja. U radu se naglašavaju sličnosti i razlike u odnosu na pravni sistem Republike Srbije, što je rezultat zajedničke pravne tradicije. Sličnosti i razlike se ispituju u odnosu na slučajeve ugrožavanja drumskog saobraćaja, imajući u vidu da je to delo propisano u svim analiziranim zakonodavstvima i da je jedno od najčešćih u praksi. Zakonodavna rešenja $\mathrm{u}$ vezi sa propisanim sankcijama (kazne i mere bezbednosti) su takođe upoređivane. $\mathrm{Na}$ osnovu uporednopravne analize, autor predlaže izmene postojećeg rešenja u pravu Republike Srbije predviđanjem teške telesne povrede učesnika u saobraćaju kao objektivni uslov inkriminacije.

Ključne reči: krivično delo, ugrožavanje bezbednosti saobraćaja, strano zakonodavstvo, kazne, mere bezbednosti. 